\title{
Dynamics of slope processes under changing land use conditions in young morainic landscapes, Western Lithuania**
}

\author{
Gintaras Jarašiūnas ${ }^{1}$, Marcin Świtoniak ${ }^{2}{ }^{*}$, and Irena Kinderiene ${ }^{1}$ \\ ${ }^{1}$ Lithuanian Research Centre for Agriculture and Forestry, Instituto Av. 1, Akademija LT-58344 Kedainiai Distr., Lithuania \\ ${ }^{2}$ Nicolaus Copernicus University, Department of Soil Science and Landscape Management, Lwowska 1, 87-100 Toruń, Poland
}

Received September 27, 2018; accepted August 30, 2019

\begin{abstract}
The long-term field study (1995-2012) concerning soil erosion was conducted on an experimental slope-plot situated on a moraine hilly agricultural landscape of the southerncentral Zemaiciai Uplands, Lithuania. The aim of the presented studies is to determine changes in the volume of soil loss under typical field crop rotation conditions with bare fallow and to estimate the impact of erosion on soil properties. Surface runoff and soil loss rates were measured on a bounded runoff plot draining to a collector tank that trapped both sediments and water. Changes in precipitation, rain intensity and land use substantially affected the rate of the erosion processes. It was found through a comparison of three-crop rotation periods that the highest intensity of slope soil transfer occurred during the time period of 2007-2012 (3rd crop rotation) due to extreme rainfall events. Developing the dynamics of vegetation cover to prevent soil erosion phenomena showed a significant difference in plant growth conditions and the suitability of various plants for soil protection. The lowest ratio of soil loss was measured on a hillslope covered by perennial grasses. The years characterized by the highest erosion rates were associated with bare fallow land use when soil losses were even 470 times higher than under perennial grasses.

Keyw ord s: soil erosion, surface runoff, young glacial landscapes, colluvial soils, crop rotation
\end{abstract}

\section{INTRODUCTION}

Accelerated erosion has led to a significant reduction in soil quality in many regions of the world (e.g. Mukundan et al., 2013; Cao et al., 2015; Panagos et al., 2015). Soil loss (SL) rates have been shown to be highly dynamic over time and in terms of area concernedlocation (e.g. Smolska 2002, 2011 ) as a result of many overlapping factors. Studies based

*Corresponding author e-mail: swit@umk.pl

**This work was conducted under the long-term research program "Productivity and sustainability of agricultural and forest soils" implemented by the Lithuanian Research Centre for Agriculture and Forestry (2010-2018). on a large set of soil loss measurements in Europe have indicated that SL is substantially influenced by land use. The highest rates were observed for bare soil surface conditions (without any plant cover), arable land and permanent crops. Much lower soil losses occurred under forest and pasture (Cerdan et al., 2006, 2010, Nacinovic et al., 2014). Dense vegetation reduces soil erosion and nutrient losses (Morgan, 2005). Perennial grasses completely protect soils from losses caused by water erosion (Fullen, 1998; Jankauskas et al., 2004) or significantly reduce its intensity even in comparison to forested areas (Li et al., 2017). Increasing the vegetation coverage effectively reduced the rate of soil erosion in recent decades on the Loess Plateau in China (Sun et al., 2014). In general, the impact of land use on SL is very important, and not just in the context of slope processes. Significant amounts of soil are also lost from the field during the harvesting of crops such as chicory roots or sugar beet (Poesen et al., 2001; Ruysschaert et al., 2005). Soil surface cover is a strategic component in the process of combating soil erosion and land degradation on hilly agricultural landscape.

Changes and inconstancy in precipitation regimes also strongly influences the nature and rate of erosion. These factors have a significant effect on the hydrological and sedimentary dynamics of the catchment scale (e.g. BoixFayos et al., 2007). This may be estimated by numerous geospatial models (e.g. Nearing et al., 2005; Kinnell, 2010). Susceptibility to wind erosion decreased logarithmically with increasing soil moisture (Zhang et al., 2018), which is closely related to the prevailing climate conditions.

(C) 2020 Institute of Agrophysics, Polish Academy of Sciences 
Lithology and geomorphic variables, such as slope gradient and length, exert a primary control over the type of erosional processes and the rate of sediment redistribution (Romero-Díaz et al., 2007). Slope inclination, length and shape have a strong influence on the velocity and volume of surface runoff (Govers, 1991; Moore and Wilson, 1992). Sun et al. (2014) confirmed that erosional processes significantly increased with slope gradient under the same type of land use. Switoniak (2014) has reported that in parts of the Brodnica moraine plateau (North Poland), which are used for agriculture the most intensive erosion zone occurs on the upper, convex parts of slopes and within the tops of hills. Kosmas et al. (2000) emphasized the importance of topography, but also noted that the slope grade has a variable effect on soil erosion in the various climatic zones of the Greek island of Lesvos. Relief is also an important "indirect" erosional factor as it is the spatial determinant of cropland systems (Van Asselen and Verburg, 2012). The distribution of steep slopes (i.e. more than $7^{\circ}$ or $15 \%$ slope steepness) is an important spatial determinant for the farm performance of undulating landscape in the Kaltinenai catchment and this natural agro-environmental variable accounts for $2.21 \%(259 \mathrm{ha})$ of the agricultural land (SRM_LT; KŽS DB5LT). An important aspect is also the direction in which the slopes are facing. In the northern hemisphere plant growth may be limited by the lower moisture content of the soil on the south-facing slopes resulting in less favourable growth conditions than on the north-facing slopes (Liu et al., 2010). The differences in vegetation-covered dunes associated with the higher moisture content of soils located on northern slopes were also confirmed in central Poland (Sewerniak and Mendyk, 2015; Sewerniak et al., 2012).

Soil texture has a certain significance on the pace of erosion. The calibration of the soil erosion rates of 21 catchments in a hilly region of central Belgium showed that silt loam and sandy silt soils under agricultural land are very sensitive to soil erosion (Van Rompaey et al., 2001). Clay content affects most key-factors, which in turn affect erosion due to infiltration, runoff rates, and aggregate stability (Poesen, 1992; Lado et al., 2004).

Soil erosion has a major influence on properties such as the amount of organic matter (SOM) and soil nutrients (Liu et al., 2010). The texture of the surface soil materials may also be changed as a result of soil truncation and the exhumation of deeper horizons (Kobierski, 2013; Świtoniak, 2014; Świtoniak et al., 2016). Consequently, this textural alteration could affect the further processes in the soil. Organic matter decomposition in light-textured (sandy) soils is faster than in heavy soils, which are rich in clay particles (Bakšiene et al., 2014). The maintenance and improvement of soil potential fertility are closely related to the maintenance of the soil organic matter and organic carbon balance, therefore a variety of soil improvement measures - fertilization with farmyard manure, green manure, the selection of the most appropriate crop rotation regime, the cultivation of plant species that are most suitable for sandy loam soils - should be employed (Tripolskaja, 2005; Wander, 2009). Soil losses also lead to the expositionsure of calcaric parent materials $(\mathrm{Ck})$ and increase the $\mathrm{pH}$ value of the surface horizons (Martinez-Casasnovas and Ramos, 2009; Świtoniak, 2014). The erosional redistribution of soil material has an effect on the amount of skeletal fractions in hilly and rocky areas (Ritchie et al., 2005). Tillage erosion is also a key-factor, which causes soil redistribution in sloping farmland in the black soil region of Northeast China (Zhao et al., 2018). Erosion induced by humans has been the main process modifying the properties of soils on the kame and morainic slopes over last two centuries (Świtoniak et al., 2014; Mendyk et al., 2016). The humus horizons of soils located on the footslope consist of a thick colluvium redeposited from the upper parts of slopes (Mendyk et al., 2014). Soils formed on colluvial sediments accumulated as a result of slope wash processes were described in many regions (e.g. Baužienè, 2008; Dotterweich, 2008; Dreibrodt et al., 2010; Podlasiński 2013; Zagórski and Kisiel, 2014). These soils are characterized by thick humus horizons (Świtoniak, 2014; Zádorová et al., 2014) exhibiting diverse characteristics e.g. chemical properties, colour or texture (Świtoniak, 2015).

Erosional processes have been monitored in Lithuania since 1960 at the Dūkštas Research Station of the Lithuanian Institute of Agriculture (Pajarskaite, 1965). Monitoring sites were established there to examine the prevailing clay loam soil in various conditions, such as bare fallow, grain crops, grasses and wasteland (untilled/uncultivated land) from 1961 to 2002 on the Baltic Uplands (Eastern Lithuania). Studies concerning soil erosion have also been carried out since 1983 (agro-environmental monitoring site) and 1994 (stationary site) in other representative physio-geographical regions under the Zemaiciai Uplands (Western Lithuania). These field experiments of erosionpreventive crop rotations were conducted and presented by Jankauskas and Jankauskiene (2003), Kinderienè et al., 2013, Jarašiūnas and Kinderienè (2016) at the Kaltinenai Research Station. The dynamics of soil loss rates over time is a significant issue of international importance. The presented study focused on the description of the dynamics of the soil loss rate in a long-term experiment in conjunction with 6-years crop rotation with bare fallow, which is a typical land use in the Baltic region. The agricultural management of this long-term crop rotation was approved and accepted by the Joint Methodological Commission of LRCAF as well as most both ecological rationale and economically valued using on agricultural hillslopes.

The aim of the presented studies is to determine changes in the volume of soil loss under typical field crop rotation conditions with bare fallow and to estimate the impact of erosion on soil properties. 


\section{MATERIALS AND METHODS}

The study was conducted on a long-term experimental plot situated on a moraine hilly agricultural landscape of the southern-central Zemaiciai Uplands, Šilale district in Western Lithuania $\left(55^{\circ} 34^{\prime} \mathrm{N}, 22^{\circ} 29^{\prime} \mathrm{E}\right.$, average altitude of $119 \mathrm{~m}$ a.s.l.) (Fig. 1a, b). The stationary field experiments investigating water erosion losses and surface runoff under different land cover and use systems on sloping fields have been carried out since 1994 at the Kaltinenai Research Station (since 2010 a sub-branch of the Vezaiciai Branch) of the Lithuanian Research Centre for Agriculture and Forestry (LRCAF).

The experiment was performed under natural rainfall erosion conditions. Using the meteorological data from the nearest meteorological station in Laukuva $\left(55^{\circ} 61^{\prime} \mathrm{N}\right.$, $22^{\circ} 23^{\prime} \mathrm{E}, 166 \mathrm{~m}$ a.s.1.), for the climate period $1960-2012$, the average annual precipitation for the area is about $842 \mathrm{~mm}$. Based on long-term observations (52-years), rainfall occurs mainly in July, August and September (80-96 mm month ${ }^{-1}$ ) (Meteorological Bulletin, 2012).

The soils of the investigated catchment represented different stages of truncation (from moderately to significantly eroded) and their epipedons had a texture of sandy loam or loamy sand. They were classified mainly as Luvisols or Retisols according to WRB (IUSS Working Group, 2015). Previously, they were also classified as Albeluvisols (Eidukevičienè and Vasiliauskienè, 2001). The parent rock in the Zemaiciai Upland is a thin layer of glacial clay loam moraine on the old base of the upland and this is an erodible moraine (Jankauskas, 1996). About 7.2\% (842 ha) and 32.4\%

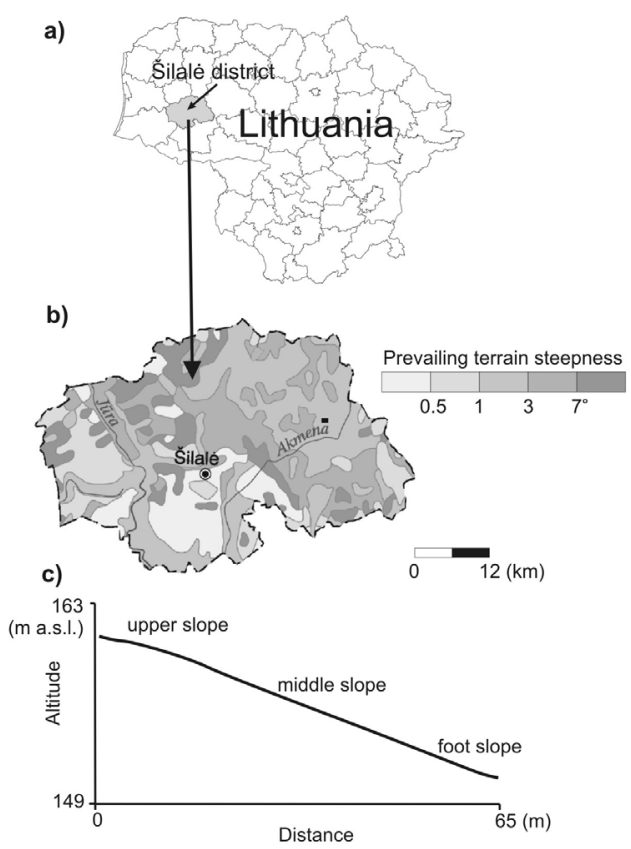

(3784 ha) of the soils have limited (poor) soil drainage and an unfavourable texture, respectively, which are significant natural agro-environmental constraints to generic agricultural activity. The major crops cultivated in the catchment farmlands are: wheat, barley and oats with mean annual yields of 3.75, 4.27 and $2.0 \mathrm{Mg} \mathrm{ha}^{-1} \mathrm{y}^{-1}$, respectively.

The field trial plot size was $208 \mathrm{~m}^{2}(3.2 \times 65 \mathrm{~m})$ (Fig. 1c). The data for the physicochemical properties of the soil, SL rates and surface runoff were measured on a south-facing slope with an average inclination of $9.9^{\circ}$. A characteristic topographic features of transect were used to divide the experimental hillslope into three slope positions. The transect method is well known in field research (Gillison and Brewer, 1985). Three slope positions, represented the catenal variability of the soils, they were selected to represent a range of topographical features common to the Zemaiciai Uplands with varying soil properties and erosion characteristics (Fig. 1c, Table 1): (i) an upper slope (US) position is slightly eroded and it could serve as a control site due to very weak but visible erosion and contribute runoff to the down slope position; (ii) the middle slope (MS) position served as a substantially eroded site and receives overland flow from the upper slope and contributes runoff to the FS slope; (iii) the foot slope (FS) position acted as accumulation segment because the two higher sediments were washed down by the through flow of water, and eroded slope sediments were trapped and had accumulated on topsoil.

The following topographical variables of slope and each sampling plot (slope position) were recorded: elevation, distance and gradient. These morphological terrain factors influence both land management strategies and

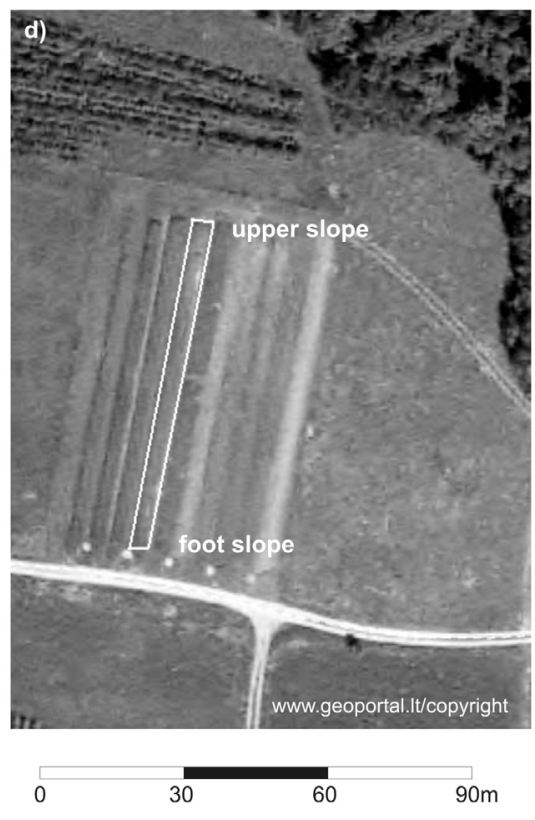

Fig. 1. Geographical position of study site: a) location of Šilale district; b) terrain morphometric map of Šilalè district; c) the slope-soil transect and slope positions in the study plot; d) orthophoto map. 
Table 1. Soil texture and bulk density of slope position plots

\begin{tabular}{|c|c|c|c|c|c|}
\hline \multirow[b]{2}{*}{ Parameter } & \multirow[b]{2}{*}{$\mathrm{n}$} & \multicolumn{3}{|c|}{ Slope positions } & \multirow[b]{2}{*}{$\mathrm{F}_{\text {act }}$} \\
\hline & & $\begin{array}{l}\text { Upper slope } \\
\text { (US) }\end{array}$ & $\begin{array}{l}\text { Middle slope } \\
\text { (MS) }\end{array}$ & $\begin{array}{l}\text { Foot slope } \\
\text { (FS) }\end{array}$ & \\
\hline Ap horizon $(\mathrm{cm})$ & 195 & $18.2 \mathrm{c}$ & $13.3 \mathrm{a}$ & $50.8 \mathrm{~b}$ & $262.85 * *$ \\
\hline Sand $(\%)$ & 27 & $89.0 \mathrm{~b}$ & $65.8 \mathrm{a}$ & $68.0 \mathrm{a}$ & $207.78 * *$ \\
\hline Silt (\%) & 27 & $6.8 \mathrm{a}$ & $24.2 \mathrm{c}$ & $25.0 \mathrm{c}$ & $107.81 * *$ \\
\hline \multirow[t]{3}{*}{ Clay (\%) } & 27 & $4.2 \mathrm{a}$ & $8.0 \mathrm{~b}$ & $9.0 \mathrm{~b}$ & $158.99 * *$ \\
\hline & & \multicolumn{4}{|c|}{ Textural class } \\
\hline & & Loamy sand & Sandy loam & Sandy loam & \\
\hline $\begin{array}{l}\text { Bulk density }\left(\mathrm{g} \mathrm{cm}^{-3}\right) \\
(0-20 \mathrm{~cm})\end{array}$ & 12 & $1.62 \mathrm{a}$ & $1.70 \mathrm{~b}$ & $1.80 \mathrm{c}$ & $13.39 * *$ \\
\hline
\end{tabular}

${ }^{* *} \mathrm{p}<0.01$ and $* \mathrm{p}<0.05$ - significance level; a,b,c, - different letters along the same row indicate statistically significant differences between slope positions; $\mathrm{n}$ - number of samples.

use practices. Topographical variables of the experimental slope-plot were determined using precise geometrical land levelling methods (equipment Zeiss Ni002 ${ }^{\circledR}$ ), providing a measurement accuracy of within $0.03 \mathrm{~m}$.

Soil sampling was performed in 2012 (after the end of the 3rd crop rotation). Soil samples with a disturbed structure, of approximately $500 \mathrm{~g}$ weight, were taken from the top $0-20 \mathrm{~cm}$ soil layer using an auger from all three of the investigated slope positions (i.e. upper slope (US), middle slope (MS) and footslope (FS)). Each sample was composed of 10 mixed replicates. In order to estimate the physical properties of the Ap horizons, samples with an undisturbed structure (metal core method) were also taken from each slope position. The thickness of the Ap horizon was estimated along the transect. A total of 27 composite soil samples ( 9 from each position) were collected for the determination of the physical and chemical soil properties.

The soil samples taken by metal cores were oven-dried at $105^{\circ} \mathrm{C}$ for $24 \mathrm{~h}$ and weighed to calculate the bulk density (Blake and Hartge, 1986). Soil samples with a disturbed structure were examined for textural class, particle size distribution (sand $2000-63 \mu \mathrm{m}$; silt $63-2 \mu \mathrm{m}$ and clay $<2 \mu \mathrm{m}$ ) and chemical properties (soil $\mathrm{pH}_{\mathrm{KCl}}$, available phosphorus $(\mathrm{P})$ and potassium $(\mathrm{K})$, soil organic carbon (SOC) and total nitrogen $\left(\mathrm{N}_{\mathrm{t}}\right)$ ).

The soil particle-size distribution was obtained using the particle-size analysis method (ISO 11277, 2009). Soil $\mathrm{pH}$ was determined for the $1 \mathrm{M} \mathrm{KCl}$ soil sample extracts using a calibrated digital $\mathrm{pH}$ meter (ISO 10390, 1994), mobile $\mathrm{P}_{2} \mathrm{O}_{5}$ and $\mathrm{K}_{2} \mathrm{O}$ extracted using the A-L method (available $\mathrm{P}$ and $\mathrm{K}$ were extracted with ammonium acetate-lactate solution, $\mathrm{pH}$ 3.7, ratio 1:20) (GOST 26208-91, 1993). Soil organic carbon (SOC) content was determined by the Tiurin dichromate-oxidation method (Nikitin, 1999; ISO 14235,1998 ) and total $\mathrm{N}$ by the Kjeldahl method (ISO
11261, 1995). Analyses of soil physicochemical properties were performed at the Agrochemical Research Laboratory of LRCAF.

The examined land management system in the longterm (18-year) field experiment was developed for a 6 year period (rotation). The composition of field crop rotation with bare fallow: 1) winter crops (Triticum aestivum L.), 2) potatoes (Solanum tuberosum L.), 3) spring barely (Hordeum vulgare L.) + under crop, 4) red clover (Trifolium pratense L.) + timothy (Phleum pratense L.), 5) spring barley (Hordeum vulgare L.), 6) bare fallow.

Soil management and fertilizer treatments were applied in accordance with measured soil properties and standard regional agricultural practices. Chemical fertilizer inputs (ammonium nitrate granulated superphosphate and potassium chloride) were used according to the plant requirements and soil properties. The main tillage, sowing, planting and harvesting directions were up-and-down the slope in order to decrease soil losses during intense rainfall (Kinderiene and Karcauskiene, 2012).

Runoff and sediment yield were monitored on the experimental slope-plot during the study period (1995-2012). A storage tank connected by a trough was placed at the end of the foot slope. Runoff and sediment yield were assessed by using a $1.5 \mathrm{~m}$ diameter tank for the storage of runoff, which was placed $2 \mathrm{~m}$ below the observation field, so the streams of water flowing down the slope were routed directly to the bottom of the slope to the water chamber, thereby directing surface water and sediments into the water and soil storage system equipped with a 2001 container. The runoff collected from the plot was manually measured within a day after each runoff event. Sediment concentrations were estimated first by oven drying (at $105^{\circ} \mathrm{C}$ ) the collected runoff samples and then weighing the sediment. This task was performed during the growing period. The amount of precipitation in the container was controlled. 
Table 2. Indicators of soil erosion by surface runoff over the three-crop rotation periods

\begin{tabular}{|c|c|c|c|c|c|}
\hline \multirow[b]{2}{*}{ Parameter } & \multicolumn{3}{|c|}{ Crop rotation } & \multirow[b]{2}{*}{$\mathrm{LSD}_{05}$} & \multirow[b]{2}{*}{ Mean $\pm S_{x}$} \\
\hline & $\begin{array}{c}\text { Ist } \\
1995-2000\end{array}$ & $\begin{array}{c}\text { IInd } \\
2001-2006\end{array}$ & $\begin{array}{c}\text { IIIrd } \\
2007-2012\end{array}$ & & \\
\hline Annual surface runoff $\left(\mathrm{hl} \mathrm{ha}^{-1} \mathrm{y}^{-1}\right)$ & 1509.8 & 530.4 & 471.3 & 465.3 & $837.2 \pm 127$ \\
\hline Soil loss rate $\left(\mathrm{t} \mathrm{ha}^{-1} \mathrm{y}^{-1}\right)$ & 23.13 & 8.99 & 38.97 & 2.99 & $23.70 \pm 15.00$ \\
\hline Rill volume measurement (n) & 58 & 26 & 51 & 5 & $45 \pm 17$ \\
\hline Precipitation $\left(\mathrm{mm} \mathrm{y}^{-1}\right)$ & 807 & 736 & 863 & 133 & $802 \pm 64$ \\
\hline Runoff coefficient & 1.87 & 0.72 & 0.55 & 0.14 & $1.05 \pm 0.72$ \\
\hline
\end{tabular}

Table 3. Measured runoff volume and SL rate due to water erosion under different crop types and land uses (1995-2012)

\begin{tabular}{|c|c|c|c|c|c|c|c|}
\hline Parameter & $\begin{array}{c}\text { Winter crops } \\
(1995,2001 \\
2007)\end{array}$ & $\begin{array}{c}\text { Potatoes } \\
(1996,2002 \\
2008)\end{array}$ & $\begin{array}{c}\text { Spring barley } \\
\text { + under crop } \\
(1997,2003, \\
2009)\end{array}$ & $\begin{array}{c}\text { Red clover } \\
+ \text { timothy } \\
\text { perennial } \\
\text { grasses }(1998, \\
2004,2010)\end{array}$ & $\begin{array}{c}\text { Spring barley } \\
(1999,2005, \\
2011)\end{array}$ & $\begin{array}{c}\text { Black fallow } \\
(2000,2006, \\
2012)\end{array}$ & $\mathrm{LSD}_{05}$ \\
\hline $\begin{array}{l}\text { Annual } \\
\text { surface runoff } \\
\left(\mathrm{hl} \mathrm{ha-1} \mathrm{y}^{-1}\right)\end{array}$ & $1168.7 \pm 905.9$ & $451.6 \pm 169.1$ & $940.6 \pm 789.1$ & $730.8 \pm 834.3$ & $804.5 \pm 748.0$ & $926.9 \pm 274.5$ & 55.3 \\
\hline $\begin{array}{l}\text { Soil loss rate } \\
\left(\mathrm{t} \mathrm{ha}^{-1} \mathrm{y}^{-1}\right)\end{array}$ & $15.84 \pm 11.83$ & $4.59 \pm 4.11$ & $26.37 \pm 38.79$ & $0.19 \pm 0.24$ & $5.87 \pm 8.15$ & $89.34 \pm 121.29$ & 5.21 \\
\hline $\begin{array}{l}\text { Precipitation } \\
\left(\mathrm{mm} \mathrm{y}^{-1}\right)\end{array}$ & $939 \pm 31$ & $656 \pm 149$ & $753 \pm 123$ & $976 \pm 103$ & $766 \pm 108$ & $721 \pm 132$ & 267 \\
\hline $\begin{array}{l}\text { Runoff } \\
\text { coefficient }\end{array}$ & $1.24 \pm 0.98$ & $0.69 \pm 0.46$ & $1.25 \pm 0.41$ & $0.75 \pm 0.72$ & $1.05 \pm 0.87$ & $1.29 \pm 0.26$ & 0.21 \\
\hline
\end{tabular}

The runoff coefficient (RC) is an important index of water recourses. The annual $\mathrm{RC}$ was defined as the ratio between annual runoff and rainfall (precipitation, $\mathrm{mm}$ ) (Savenije, 1996).

The area has an upland geomorphology and thus an abundance and intensity of precipitation have created favourable natural conditions for the erosion of soils by water (Kudaba, 1983). Soil erosion was mainly caused by tillage and water erosion under continuous intensive cropping. Sheet and rill erosion forms were prevailing in the field plot. This plot mainly had long rills.

Water erosion rates of the agro-environmental stationary site were assessed by measuring the length and cross-sectional area of the rills in order to calculate soil loss volume (Chambers et al., 2000; Steegen et al., 2000; Van Rampaey et al., 2001; Øygarden, 2003). The volume of soil losses by rill erosion were calculated using formula:

$$
x=\left[\left(\Sigma l_{1} p_{1}+\Sigma l_{2} p_{2}+\ldots \Sigma l_{n} p_{n}\right): n\right]: y,
$$

where: $x\left(\mathrm{~m}^{-3} \mathrm{ha}^{-1}\right)$ is the volume of rill erosion; $l, l_{1}, \ldots$ $l_{n}\left(\mathrm{~cm}^{-1}\right)$ is the rill depth; $p, p_{1}, \ldots p_{n}\left(\mathrm{~cm}^{-1}\right.$, accuracy \pm 0.1 $\left.\mathrm{cm}^{-1}\right)$ is the rill width; $n$ is the number of rills on the measured plot width; $y\left(\mathrm{~m}^{-1}\right)$ is the measured plot width; $\Sigma$ is the sum of the performed measurements from selected $1 \mathrm{~m}$ length segments located at equal distances on the experimental plot.
This method may be used with relative ease in areas where rill erosion represents the dominant sediment source (Govers and Poesen, 1988; Vanmaercke et al., 2012; Maetens et al., 2012). Plot runoff and erosion were measured at regular intervals, every week, or after rainfall and sowing. Measurements were taken from spring sowing (typically late April or early May) to mid-June for cereals. During the investigated period, rill erosion measurements were taken 134 times.

A one-way analysis of variance (ANOVA) was used to estimate the significance of differences at $p<0.01$ and $p<0.05$ to compare the means of soil variables using Duncan's multiple range test when the results of ANOVA were significant at $p<0.05$. The means of the least significant difference (LSD) at $\mathrm{p}=0.05$ are presented in Tables 2 and 3. A statistical analysis was carried out using the SPSS software package (Field, 2009). A correlation - regression analysis (Clewer and Scarisbrick, 2001) was used to evaluate the relationship (non-parametric Spearman's rho test) between annual runoff volume (RV) and SL rate, the amount of annual precipitation and the annual RV, annual precipitation and SL rate and annual RC and SL rate.

\section{RESULTS}

Generally, the field experiment area is located in undulating landscape with large and steeply divided hills ( $\left.\geq 8-12^{\circ}\right)$ where the average slope length is $\geq 100 \mathrm{~m}$. The average 
Table 4. Terrain attributes of the experimental plot

\begin{tabular}{|c|c|c|c|c|c|c|}
\hline Position & Plot length (m) & Area $\left(\mathrm{m}^{2}\right)$ & Altitude range (m) & $\begin{array}{l}\text { Relative altitude } \\
\text { difference }(\mathrm{m})\end{array}$ & $\begin{array}{c}\text { Slope gradient } \\
(0 / \%)\end{array}$ & $\begin{array}{l}\text { Slope } \\
\text { aspect }\end{array}$ \\
\hline Slope & 65 & 208.0 & $161.669-150.642$ & 11.027 & $9.9 / 22.0$ & South \\
\hline \multicolumn{7}{|c|}{ Slope positions } \\
\hline Upper slope & 7 & 22.4 & $161.669-160.782$ & 0.887 & $7.3 / 16.2$ & South \\
\hline Middle slope & 35 & 112.0 & $160.782-154.470$ & 6.312 & $10.6 / 23.6$ & South \\
\hline Foot slope & 23 & 73.6 & $154.470-150.642$ & 3.828 & $9.7 / 21.6$ & South \\
\hline
\end{tabular}

gradient of the experimental slope was $9.9^{\circ}$ (Table 4). On each slope position it ranges from 7.3 and $9.7^{\circ}$ on the US and FS positions, respectively to the steepest value of $10.6^{\circ}$ on the MS position. The hillslope had $11 \mathrm{~m}$ of relative altitude difference between 161.7 and $150.6 \mathrm{~m}$ a.s.1. The MS position had the greatest altitude differences of about $6.3 \mathrm{~m}$.

Topsoil layer thickness shows significant differences between all of the sloped positions. Compared with the FS position, in US and MS it was more than 4 times thinner (Table 2).

Surface soil textures varied from loamy sand in the US position to sandy loam in the MS and FS positions. In all slope positions the soil was characterized by a high sand content, which on the upper part of the slope (US) was $89 \%$. In soils from the MS and FS positions, the percentage of sand was lower by 26 and $24 \%$ respectively compared to the US position. The percentage of sand, silt and clay was almost identical in the MS and FS slope positions. The silt and clay contents were much higher in the MS and FS slope positions compared with US. Silt and clay is almost absent in the top horizon in the US position.

The bulk density of the soil of each studied slope position varied to a statistically significant degree (Table 2). The values of bulk density increased downslope with results of $1.62,1.70$ and $1.80 \mathrm{~g} \mathrm{~cm}^{-3}$ for US, MS and FS, respectively. The increased bulk density values in the downslope direction may be attributed to ascending SOM content and an increasing concentration of silt-clay particles.

The statistically significant higher soil $\mathrm{pH}$ mean value was determined in the US position soil compared with the MS and FS position (Table 5). The base of the slope and the middle part of it showed very similar values of $\mathrm{pH}$. The average soil organic matter (SOM) contents of the slope positions were $0.7,1.5$ and $1.7 \%$ at the US, MS and FS positions, respectively. The soil of US position had very low SOM content.

Total nitrogen $\left(\mathrm{N}_{\mathrm{t}}\right)$ content was generally very low, and the pattern of its distribution closely follows that of soil organic matter. With regard to sediment transport, the accumulation of $\mathrm{N}_{\mathrm{t}}$ increased in the downslope direction: $0.067 \%$ (US), $0.079 \%$ (MS) and $0.085 \%$ (FS). Consequently, differences in $\mathrm{N}_{\mathrm{t}}$ under the slope positions were small and statistically non-significant $(\mathrm{p} \geq 0.05)$. Higher contents of $\mathrm{P}_{2} \mathrm{O}_{5}$ were obtained at the US and FS, that is, $177 \mathrm{mg} \mathrm{kg}^{-1}$ and $125 \mathrm{mg} \mathrm{kg}^{-1}$, respectively. The soil in the MS position had a very low content of $\mathrm{P}_{2} \mathrm{O}_{5}\left(107 \mathrm{mg} \mathrm{kg}^{-1}\right)$. In the US soil, the $\mathrm{P}_{2} \mathrm{O}_{5}$ content was 29 and $40 \%$ higher than that in the FS and MS position soils, respectively.

Topographically, $\mathrm{K}_{2} \mathrm{O}$ in the surface soil of the three slope positions showed a regular trend, which followed that of the highest content in FS (142 $\mathrm{mg} \mathrm{kg}^{-1}$ ), less in MS (139 $\left.\mathrm{mg} \mathrm{kg}^{-1}\right)$ and the lowest in US soil (115 $\left.\mathrm{mg} \mathrm{kg}^{-1}\right)$. Due to the erosion processes in the MS and FS positions, the $\mathrm{K}_{2} \mathrm{O}$ contents were 17 and 19\% higher than those found at the US position soils found at higher altitudes. In general, the severely eroded soil studied may be classified as moderately rich in available $\mathrm{K}$.

The average annual air temperature in the experiment site over the 1 st crop rotation period (1995-2000) was $6.3^{\circ} \mathrm{C}$, over the 2 nd cropping period (2001-2006) it was $6.6^{\circ} \mathrm{C}$ and over the 3 rd crop rotation period (2007-2012) it was $6.8^{\circ} \mathrm{C}$ (Fig. 2). The estimated average temperature in

Table 5. Soil chemical properties of slope position plots

\begin{tabular}{|c|c|c|c|c|c|}
\hline \multirow{2}{*}{ Parameter } & \multirow{2}{*}{$\mathrm{n}$} & \multicolumn{3}{|c|}{ Slope positions } & \multirow{2}{*}{$\mathrm{F}_{\text {act }}$} \\
\hline & & Upper slope (US) & Middle slope (MS) & Foot slope (FS) & \\
\hline $\mathrm{pH}_{\mathrm{KCl}}$ & 27 & $7.3 \mathrm{~b}$ & $6.5 \mathrm{a}$ & $6.6 \mathrm{a}$ & $11.2^{*}$ \\
\hline SOM (\%) & 27 & $0.7 \mathrm{a}$ & $1.5 \mathrm{~b}$ & $1.7 \mathrm{c}$ & $14.59 * *$ \\
\hline $\mathrm{N}_{\mathrm{t}}(\%)$ & 27 & 0.067 & 0.079 & 0.085 & 1.11 \\
\hline Mobile $\mathrm{P}_{2} \mathrm{O}_{5}\left(\mathrm{mg} \mathrm{kg}^{-1}\right)$ & 27 & $177 \mathrm{~b}$ & $107 \mathrm{a}$ & $125 \mathrm{a}$ & $56.36^{* *}$ \\
\hline Mobile $\mathrm{K}_{2} \mathrm{O}\left(\mathrm{mg} \mathrm{kg}^{-1}\right)$ & 27 & $115 \mathrm{a}$ & $139 \mathrm{c}$ & $142 \mathrm{c}$ & $25.04 * *$ \\
\hline
\end{tabular}

Explanations as in Table 1. 


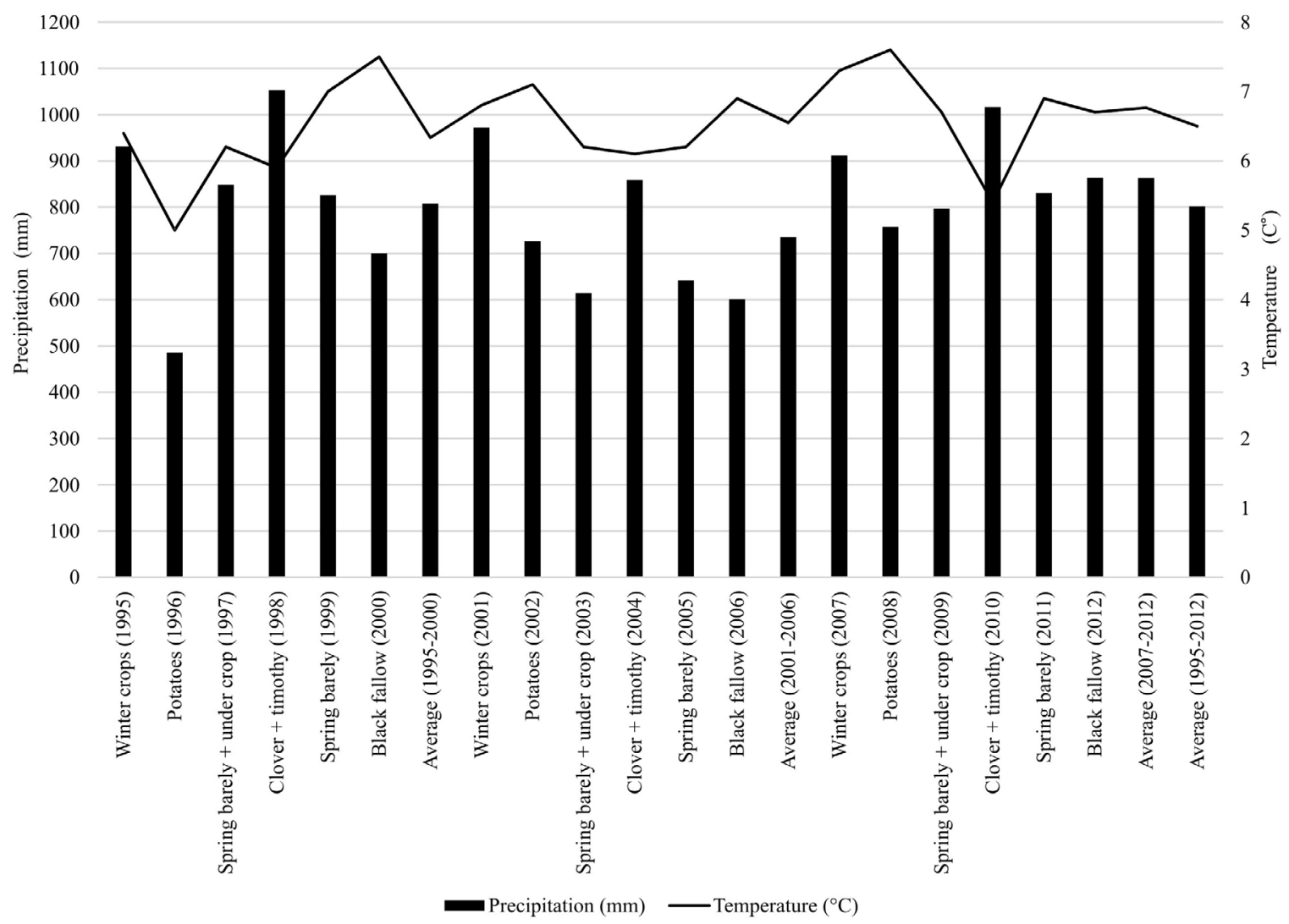

Fig. 2. Annual precipitation and temperature.

the study area was $6.5^{\circ} \mathrm{C} /$ year for $1995-2012$. The coldest year was 1996 (potatoes treatment) with an average temperature of $5.0^{\circ} \mathrm{C}$ and the warmest year was 2008 (potatoes treatment) with an average of $7.6^{\circ} \mathrm{C}$. During all three cropping periods, the highest amount of precipitation recorded in 1998 (clover + timothy treatment) was $1052.4 \mathrm{~mm} \mathrm{y}^{-1}$, thus the lowest amount of precipitation was in 1996 (potatoes treatment) at $485.4 \mathrm{~mm} \mathrm{y}^{-1}$. The annual surface runoff volume (Table 4) under the long-term natural rainfall erosion plot extends to 18-years and shows that the annual mean was $837.2 \mathrm{hl} \mathrm{ha}^{-1} \mathrm{y}^{-1}$. The 3rd crop rotation showed slightly lower $(11 \%)$ surface runoff compared to the 2 nd crop rotation, while during the 1 st crop rotation surface runoff volume was much higher than during the other two rotations. The linear relationship between the annual runoff volume and the SL rate was statistically significant $(r=0.743, p=0.001, n=18)$.

The greatest annual SL rate on the $9.9^{\circ}$ slope under the field crop land-use system with the bare fallow was during the 3 rd crop rotation period, while it was $41 \%$ lower during the 1 st and $77 \%$ lower during the 2 nd rotations.

No significant $(p>0.05)$ differences have been estimated in precipitation amounts by period of crop rotations. The results indicated that during the 2 nd crop rotation, the mean annual precipitation was 8.8 and $14.7 \%$ lower than those during the 1st and 3rd crop rotations, respectively. The annual amount of precipitation increased $6.5 \%$ for the period 2007-2012 (3rd crop rotation) compared with the period of 1995-2000 (1st crop rotation). Moderate and significant correlation was found between the amount of annual precipitation and the annual runoff volume $r=0.557, p=0.029, n=18$ ). Thus, there was weak relationship between annual precipitation and the SL rate $(r=0.279$, $\mathrm{p}=0.431, \mathrm{n}=18$ ).

The results of our study show marked differences in runoff coefficient (RC) by crop rotation periods. RC was $1.87,0.72$, and 0.55 for the 1 st, 2 nd and 3rd crop rotations, respectively. The RC value was $62 \%$ higher during the 1 st crop rotation than that in the 2 nd crop rotation, and the RC value during the 3 rd crop rotation was $24 \%$ lower compared to the 2 nd crop rotation.

The erosion-protection capabilities of different land use systems varied widely. The results obtained showed that the differences in SL rate between different crop types of study plot were highest $\left(0.19\right.$ and $89.34 \mathrm{tha}^{-1} \mathrm{y}^{-1}$ on average, respectively) under the red clover + timothy grass mixture and bare fallow (Table 5). According to the mean data of 18-years of field-plot investigation, the mean annual SL rate under bare fallow field conditions increased by 82.3 , 94.9, 70.5, 99.8 and $93.4 \%$ compared with winter crops 
(winter rye), potatoes, spring barley + under crop, red clover + timothy grasses and spring barley, respectively. Even red clover + timothy grasses in the early growth stages of the plant could not completely eliminate the soil erosion hazard.

On a hillslope of $9.9^{\circ}$ with an altitude of $161.669 \mathrm{~m}$ a.s.1., the long-term average of the SL rate under vegetated cover (excludes bare soil treatment) was $10.57 \mathrm{tha}^{-1} \mathrm{y}^{-1}$ and it is more than 8 times lower compared with bare soil where rill erosion is mainly defined by surface runoff and is highly sensitive to sheet and rill erosion. In comparisonntrast, the average runoff volume under vegetation cover was $819.2 \mathrm{hl}$ $\mathrm{ha}^{-1} \mathrm{y}^{-1}$ and this decreased due the increase in infiltration by $11.6 \%$ compared to the bare slope.

Based on the data of 18-years of field-plot experiments for six land use systems, it was found that the highest runoff volume was from winter crops $\left(1168.7 \mathrm{hl} \mathrm{ha}^{-1} \mathrm{y}^{-1}\right)$ and the lowest one was from potato plots $\left(451.6 \mathrm{hl} \mathrm{ha}^{-1} \mathrm{y}^{-1}\right)$. With respect to the data produced by 18 years of field investigations, the measured runoff results show that the highest volume occurred under winter crops in $1995(2186 \mathrm{hl}$ $\left.\mathrm{ha}^{-1}\right)$, under spring barley + under crop in 1997 (1 $831 \mathrm{hl}$ $\left.\mathrm{ha}^{-1}\right)$, under red clover + timothy grasses and spring barley in 1999 and $2000\left(1684-1660 \mathrm{hl} \mathrm{ha}^{-1} \mathrm{y}^{-1}\right)$, respectively. In addition, a high runoff volume was recorded under bare fallow in $2000\left(1068 \mathrm{hl} \mathrm{ha}^{-1}\right)$ and in $2012\left(1102.2 \mathrm{hl} \mathrm{ha}^{-1}\right)$. Relatively low measured runoff volumes (which did not exceed $400 \mathrm{hl} \mathrm{ha}^{-1}$ ) were recorded under red clover + timothy multiannual grass growing in $2004\left(133.2 \mathrm{hl} \mathrm{ha}^{-1}\right)$, under spring barley in $2011\left(273.7 \mathrm{hl} \mathrm{ha}^{-1}\right)$ and in 2008, 2009 and 2010 under spring barley + under crop (327.6 hl $\left.\mathrm{ha}^{-1}\right)$, under potatoes (333.9 hl ha $\mathrm{ha}^{-1}$ and under red clover + timothy grasses $\left(375.2 \mathrm{hl} \mathrm{ha}^{-1}\right)$, respectively. Bare soil treatment should attract considerable attention because of its sensitivity to soil degradation. Runoff on bare soil cover

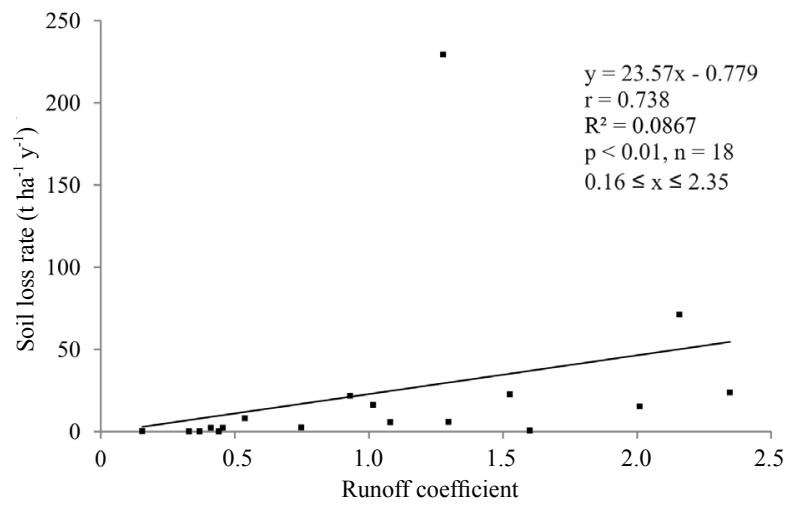

Fig. 3. Relationship between runoff coefficient and SL rate over long-term field crop with bare fallow rotation plants.

exceeds $926.9 \mathrm{hl} \mathrm{ha}^{-1} \mathrm{y}^{-1}$ with the highest amount occurring in $2012\left(1102.2 \mathrm{hl} \mathrm{ha}^{-1}\right)$, and this falls to $610.6 \mathrm{hl} \mathrm{ha}^{-1}$ in 2006.

Annual RC ranged from 0.69 under potatoes to 1.24 1.29 under winter crops, spring barley + under crop and bare fallow. In the potato plot and red clover + timothy grass use, the RC was $46.5-41.9 \%$ lower than under bare fallow. According to the data of 18 years of field investigations, the lowest $(0.16) \mathrm{RC}$ was recorded in 2004 under red clover + timothy grass cover, thus the highest (2.35) occurred in 1995 under winter crop treatment, respectively. It was found that $\mathrm{RC}$ has an important and statistically significant effect on the SL rate $(\mathrm{r}=0.738, \mathrm{p}=0.001, \mathrm{n}=18)$ (Fig. 3).

\section{DISCUSSION}

The obtained results indicate strong erosive alterations in soil cover along the investigated transect (Fig. 4). In the US and MS positions, soil material was gradually loosened through surface erosion, whereby the A horizon in the FS position became thicker due to the influx of humic

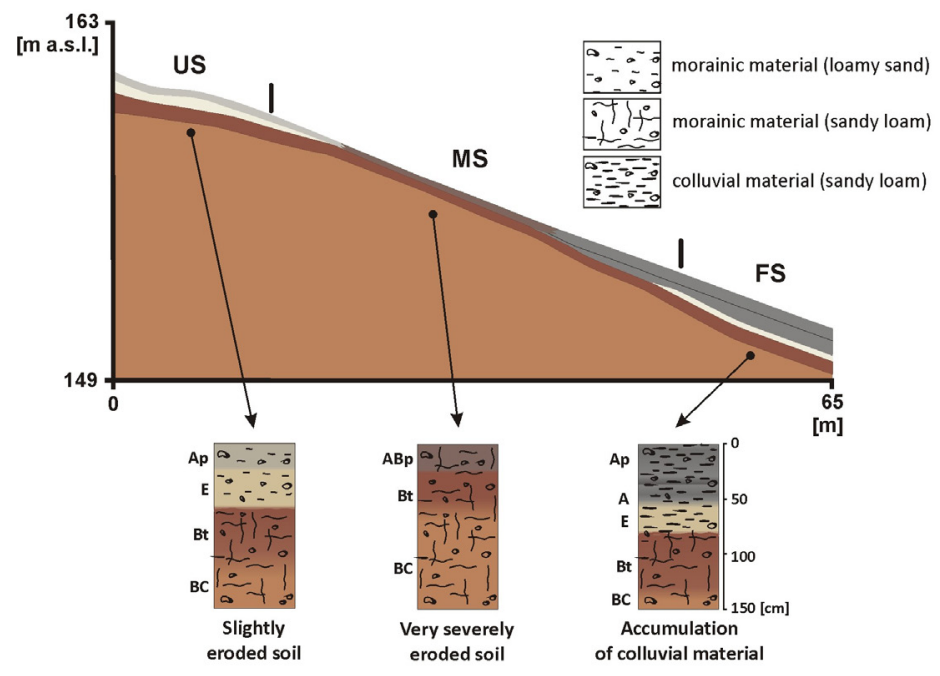

Fig. 4. Sequence of soils along investigated transect. 
soil material. Additionally, the sedimentary layering of the A horizon at the FS position was clearly visible, this confirms the colluvial character of it (Dreibrodt et al., 2010; Lang, 1999; IUSS Working Group WRB, 2015). In most cases, which were described by another author, the differences in thickness of the Ap layer in hilly areas may be due to soil erosion (e.g. Lal, 1998). Moreover, the contents of $\mathrm{SOC}$ and $\mathrm{N}_{\mathrm{t}}$ in the A horizon were highest in FS position. The reason for the low amount of SOM at the US position was believed to be due to the SOM, which was normally redistributed with the physical transportation of soil particles down the slope. Bergstrom et al. (2001) noted that the input of eroded materials to the low-lying land increased SOM content in the foot-slope position. The initially eroded material in the surface soil at the FS position originated from the US position. SOM losses are highest in the summit position (Pennock et al., 1994). It is especially noteworthy that the reduction in SOM makes the soil more erodible and produces a sudden decrease in the resistance to erosion (Jarašiūnas and Kinderienè, 2016). This was also confirmed by Pierson and Mulla (1990) and Zádorová et al. (2011). They found the highest SOC content in the FS position and the lowest one at the US.

The reason for the higher stocks of organic carbon in soils located in the lower part of the slope is also the increase in their moisture content, which slows down the decomposition of organic matter and leads to its accumulation. This is indicated by the high SOM content in the soil located at the FS position - more than two times greater than in the uppermost profile. Similar toposequence-induced changes in soil water regimes were described in the young morainic landscapes of Poznań Lakeland by Kozłowski and Komisarek (2017).

The low content of the silt and clay fraction in the Ap horizon in the US position may stem from two factors related to erosion. Firstly, the profile located in the upper slope represents slightly eroded Luvisol with a well-developed eluvial zone (Ap and $\mathrm{E}$ horizons) in which the clay content was depleted by illuvial translocation of this fraction into a deeper Bt horizon. Luvisols or Albeluvisols with the loamy sand texture of Ap horizons were described in many young morainic areas of Lithuania (Jankauskas and Fullen, 2002) Poland (e.g. Świtoniak, 2014) or Germany (Kühn, 2003). Secondly, the low content of fine fractions in the US position suggest high rates of downslope surface wash of silt and clay. However, there were slight differences between the silt and clay contents between the MS and FS positions. The finer texture of the surface horizons in these two positions may be the result of Bt excavation in the middle slope (Fig. 2). The partial substitution of soil material in the Ap horizons of soils situated in the lower topographic positions was due to the erosion of soils and the exposure of the Bt horizons located within the upper or middle slopes as described in other regions previously (Mroczek and Rodzik, 2011; Świtoniak et al., 2016).
Over the long-term study, the thickness of the lost soil layer in the hilly landscape was very different and related to precipitation intensity, soil texture and slope-plot cover. Panagos et al. (2015) has estimated that the mean SL rate in the European Union's erosion-prone lands can be estimated asat $2.46 \mathrm{t} \mathrm{ha}^{-1} \mathrm{y}^{-1}$. The annual SL rate over the research period 1995-2012 crop rotation on the $9.9^{\circ}$ hillslope with loamy sand and sandy loam soil texture in the Western Lithuanian climate condition varied from 8.99 to $38.97 \mathrm{t}$ $\mathrm{ha}^{-1}$ (it was not significantly affected by the average annual precipitation). The average losses of soil due to erosion in this landscape, where a variety of varying crops were grown, was on average $23.70 \mathrm{t} \mathrm{ha}^{-1} \mathrm{y}^{-1}$ and according to Zachar (1982) this could be evaluated as a severe erosion rate. Extreme rainfall events in autumn (2009) and summer (2012) were the cause of most cases of rainwash, rill formation and soil loss occurrence.

Climate warming processes (about $+0.7^{\circ} \mathrm{C}$ over the period of more than 30 years, Galvonaite et al., 2013) and a positive air temperature encouraged snow melting and runoff water to flow down the slope surface, even during the cold period (Kinderiene and Karcauskiene, 2012). A long period (27-years) of erosive process activity on Eutric Albeluvosols (sandy loam) had a great impact on the upper layer redistribution and the critical slope segments (erosive zones) of the steep slope formation leading to geomorphologic change and the degradation of hills (Jarašiūnas and Kinderiené, 2016). The influence of land-use types on soil erosion loss is evident. The mean water erosion rate varied from 0.19 to $89.34 \mathrm{t} \mathrm{ha}^{-1} \mathrm{y}^{-1}$. Slope surface plant cover with perennial grasses (red clover + timothy) resulted in relatively small, comparable with naturally occurring soil erosion losses by water (Jankauskas et al., 2004). Significant differences between individual years representing the same type of crop (Table 5) may be related to the yearly dynamics of the slope processes. High interannual changes in soil losses $\left(37-259 \mathrm{t} \mathrm{km}^{-2} \mathrm{y}^{-1}\right)$, were measured even within the no-till catchment in Southern Brazil (Didoné et al., 2017). Winter and summer cereals growing on steep hills withstood moderate to high soil losses, however their cultivation should be strictly limited.

Precise seasonal runoff analysis and seasonal climatic data evaluation were not a priority in the study. The exceptional very dry weather conditions in the months of spring were fixed during the whole study period. The most abundant rains and water leakage during the long-term experimental periods prevailed in the summer and autumn months. Erosional processes on bare soil (fallow treatment) were the most hazardous in these climatic seasons. The most extreme erosional situation occurred in 2012 over the six-year rotation period in bare fallow treatment. The storm rainfall during the summer and autumn months in 2012 was the natural cause of the rain-wash processes deep $(8-24 \mathrm{~cm})$ and wide $(11-58 \mathrm{~cm})$ rills occurred and high soil losses were recorded. 
Research concerning the impact of snowmelt impact on erosional processes was not performed in this field experiment. We can only provide general observations (without statistical data) of snowmelt processes in the study area. Rapid snow melting and the simultaneous leaking of water streams on the hillslopes were driven by rainfall. The soil infiltration capacity is zero when the soil is frozen. In Lithuania, the melting of snow and water flow down the slope most often occurs at the same time.

\section{CONCLUSIONS}

The study allows for the formulation of the following conclusions:

1 . The intensity of the slope processes changed significantly during the investigated period, which was dependent on overlapping factors - both natural and related to different land use during particular years.

2. The soil loss rate and rill volumes had a weak relationship with the amount of annual precipitation, it was closely correlated with extreme events of rainfall.

3. Due to the uneven distribution of intensive rainfall, the same crop rotation with similar annual precipitation was characterized by very diverse values of annual surface runoff and soil loss rates.

4. The erosion-protection capabilities of different land use systems varied widely. The lowest ratio of soil loss was measured on a hillslope covered by perennial grasses. These losses were several times smaller despite the greater precipitation occurring compared to the years of growing crops or potatoes. The years characterized by the highest rate of erosion were associated with bare fallow land use when soil losses were up to 470 times higher than under perennial grasses.

5. The redistribution of mineral material by slope processes led to significant changes in soil properties along the investigated transect. Pedons in the upper slope position were depleted in organic carbon content. Colluvial material rich in humus was deposited in the foot slope position.

6. Many aspects of erosion processes are still not satisfactorily understood and require further research. For example, it is necessary to carry out detailed measurements at short intervals, which would allow for a precise determination of the relationship between the intensity of rainfall and slope processes.

Conflict of interest: The Authors do not declare conflict of interest.

\section{REFERENCES}

Bakšienė E., Ražukas A., Repečkienė J., and Titova J., 2014. Influence of different farming systems on the stability of low productivity soil in Southeast Lithuania. ZemdirbysteAgriculture, 101(2), 115-124. https://doi.org/10.13080/z-a.2014.101.015
Baužienė I., Świtoniak M., and Charzyński P., 2008. Properties of deluvial soils in Poland and Lithuania and propositions for their classification. Žemès ūkio mokslai, 15(3), 29-35.

Bergstrom D.W., Monreal C.M., and Jacques St.E., 2001. Spatial dependence of soil organic carbon mass and its relationship to soil series and topography. Can. J. Soil Sci., 81 (1), 53-62. https://doi.org/10.4141/s00-016

Blake G.R. and Hartge K.H., 1986. Bulk density. In: Methods of Soil Analysis: Part I. Physical and mineralogical methods (Ed. A. Klute). ASA, Monograph, No. 9. Madison, WI, USA. https://doi.org/10.2136/sssabookser5.1.2ed.c13

Boix-Fayos C., Barberá G.G., López-Bermúdez F., and Castillo V.M., 2007. Effects of check-dams, reforestation and landuse changes on river channel morphology: case study of the Rogativa catchment (Murcia, Spain). Geomorphology, 91(1), 103-123. https://doi.org/10.1016/j.geomorph.2007.02.003

Cao L., Zhang Y., Lu H., Yuan J., Zhu Y., and Liang Y., 2015. Grass hedge effects on controlling soil loss from concentrated flow: a case study in the red soil region of China. Soil Till. Res., 148, 97-105. https://doi.org/10.1016/j.still.2014.12.009

Cerdan O., Govers G., Le Bissonnais Y., Van Oost K., Poesen J., Saby N., Gobin A., Vacca A., Quinton J., Auerswald K., Klik A., Kwaad F.J.P.M., Raclot D., Ionita I., Rejman J., Rousseva S., Muxart T., Roxo M.J., and Dostal T., 2010. Rates and spatial variations of soil erosion in Europe: a study based on erosion plot data. Geomorphology, 122 (1-2), 167-177. https://doi.org/10.1016/j.geomorph.2010.06.011

Cerdan O., Poesen J., Govers G., Saby N., Le Bissonnais Y., Gobin A., Vacca A., Quinton J., Auerswald K., Klik A., Kwaad F.P.M., Roxo M.J., 2006. Sheet and rill erosion. In: Soil Erosion in Europe (Eds J. Boardman, and J. Poesen. Chichester: Wiley, 501-513. https://doi.org/10.1002/0470859202.ch38

Chambers B.J., Garwood T.W.D., and Unwin R.J., 2000. Controlling soil water erosion and phosphorus losses from arable land in England and Wales. J. Environ. Qual., 29(1), 145-150. https://doi.org/10.2134/jeq2000.00472425002900010018x

Clewer A.G. and Scarisbrick D.H., 2001. Practical statistics and experimental design for plant and crop science. New York, USA.

Didoné E. J., Minella J. P.G., and Evrard O., 2017. Measuring and modelling soil erosion and sediment yields in a large cultivated catchment under no-till of Southern Brazil. Soil Till. Res., 174,24-33.https://doi.org/10.1016/j.still.2017.05.011

Dotterweich M., 2008. The history of soil erosion and fluvial deposits in small catchments of central Europe: deciphering the long-term interaction between humans and the environment - a review. Geomorphology, 101(1), 192-208. https://doi.org/10.1016/j.geomorph.2008.05.023

Dreibrodt S., Lubos C., Terhorst B., Damm B., and Bork H.R., 2010. Historical soil erosion by water in Germany: scales and archives, chronology, research perspectives. Quatern. Int., 222(1), 80-95.https://doi.org/10.1016/j.quaint.2009.06.014

Eidukevičienè M. and Vasiliauskienè V., 2001. Soils of Lithuania (in Lithuanian). Vilnius: Lietuvos mokslas, Lithuania.

Field A., 2009. Discovering Statistics Using SPSS. London: Sage publications. 
Fullen M.A., 1998. Effects of grass ley set-aside on runoff, erosion and organic matter levels in sandy soils in east Shropshire, UK. Soil Till. Res., 46(1-2), 41-49. https://doi.org/10.1016/s0167-1987(98)80106-2

Galvonaitė A. Kilpys J., Kitrienė Z., and Valiukas D., 2013. Climate average for Lithuania 1981-2010) (in Lithuanian). Climatology Division at Lithuanian Hydrometeorological Service under the Ministry of Environment.

Gillison A.N. and Brewer K.R.W., 1985. The use of gradient directed transects or gradsects in natural resource surveys. J. Environ. Manag., 20, 103-127.

GOST 26208-91: 1993. Soils. Determination of mobile compounds of phosphorus and potassium by Egner-RiemDomingo method (AL-method). Moscow, Russia.

Govers G., 1991. Rill erosion on arable land in Central Belgium: rates, controls and predictability. Catena, 18(2), 133-155. https://doi.org/10.1016/0341-8162(91)90013-n

Govers G. and Poesen J., 1988. Assessment of the interrill and rill contributions to total soil loss from an upland field plot. Geomorphology, 1(4), 343-354. https://doi.org/10.1016/0169-555x(88)90006-2

ISO 10390: 1994. Soil quality. Determinatio of $\mathrm{pH}$. TC 190/SC 3.

ISO 11261: 1995. Soil quality. Determination of total nitrogen Modified Kjeldahl method. TC 190/SC 3.

ISO 11277: 2009. Soil quality - Determination of particle size distribution in mineral soil material - Method by sieving and sedimentation. International Organization for Standardization. Geneva, Switzerland, 46. https://doi.org/10.3403/30202674

ISO 14235: 1998. Soil quality. Determination of organic carbon by sulfochromic oxidation. TC 190/SC 3.

IUSS Working Group WRB, 2015. World Reference Base for soil resources 2014. International soil classification system for naming soils and creating legends for soil maps. Update 2015. World Soil Resources Report No. 106. FAO: Rome. https://doi.org/10.1007/springerreference_76722

Jankauskas B., 1996. Soil erosion. Vilnius: Margi rastai, 168 (in Lithuanian).

Jankauskas B. and Fullen M.A., 2002. A pedological investigation of soil erosion severity on undulating land in Lithuania. Can. J. Soil Sci., 82(3), 311-321.

https://doi.org/10.4141/s01-058

Jankauskas B. and Jankauskiene G., 2003. Erosion-preventive crop rotations for landscape ecological stability in upland regions of Lithuania. Agr. Ecosyst. Environ., 95(1), 129-142. https://doi.org/10.1016/s0167-8809(02)00100-7

Jankauskas B., Jankauskiene G., and Fullen M.A., 2004. Erosion-preventive crop rotations and water erosion rates on undulating slopes in Lithuania. Can. J. Soil Sci., 84(2), 177-186. https://doi.org/10.4141/s03-029

Jarašiūnas G. and Kinderienė I., 2016. Impact of agro-environmental systems on soil erosion processes and soil properties on hilly landscape in Western Lithuania. J. Environ. Eng. Landsc., 24 (1), 60-69. https://doi.org/10.3846/16486897.2015.1054289

Kinderienė I., Jarašiūnas G., and Karčauskienė D., 2013. Loss of plant nutrients $(\mathrm{N}, \mathrm{P}, \mathrm{K})$ with soil loss and water runoff from hill slopes (in Lithuanian). Žemès ūkio mokslai 20(1), 10-19. https://doi.org/10.6001/zemesukiomokslai.v20i1.2634

Kinderiene I. and Karcauskiene D., 2012. Effects of different crop rotations on soil erosion and nutrient losses under natural rainfall conditions in Western Lithuania. Acta Agr. Scand., B-S. P. 62 (sup2), 199-205.

https://doi.org/10.1080/09064710.2012.714400

Kinnell P.I.A., 2010. Event soil loss, runoff and the Universal Soil Loss Equation family of models: a review. J. Hydrol., 385(1), 384-397. https://doi.org/10.1016/j.jhydrol.2010.01.024

Kobierski M., 2013. Morphology, properties and mineralogical composition of eroded Luvisols in selected morainic areas of the Kujavian and Pomeranian Province. University of Technology and Life Sciences, Bydgoszcz, Poland.

Kosmas C., Danalatos N.G., and Gerontidis St., 2000. The effect of land parameters on vegetation performance and degree of erosion under Mediterranean conditions. Catena, 40(1), 3-17. https://doi.org/10.1016/s0341-8162(99)00061-2

Kozłowski M. and Komisarek J., 2017. Temporal water table changes in soil toposequence of the Poznań Lakeland (Western Poland). Soil Science Annual, 68(4), 167-173.

Kudaba Č., 1983. Uplands of Lithuania (in Lithuanian). Mokslas: Vilnius, Lithuania.

Kühn P., 2003. Micromorphology and Late Glacial/Holocene genesis of Luvisols in Mecklenburg-Vorpommern (NE-Germany). Catena, 54(3), 537-555.

https://doi.org/10.1016/s0341-8162(03)00129-2

KŽS_DB5LT, 2017. Control Land Parcels Database. Lithuanian State Land Fund database.

Lado M., Ben-Hur M., and Shainberg I., 2004. Soil wetting and texture effects on aggregate stability seal formation and erosion. Soil Sci. Soc. Am. J., 68(6), 1992-1999.

https://doi.org/10.2136/sssaj2004.1992

Lal R., 1998. Soil erosion impact on agronomic productivity and environment quality. Crit. Rev. Plant Sci., 17(4), 319-464. https://doi.org/10.1016/s0735-2689(98)00363-3

Lang A. and Hönscheidt S., 1999. Age and source of colluvial sediments at Vaihingen-Enz. Germany. Catena, 38(2), 89-107. https://doi.org/10.1016/s0341-8162(99)00068-5

Li Z., Liu C., Dong Y., Chang X., Nie X., Liu L., Xiao H., Lu Y., and Zeng G., 2017. Response of soil organic carbon and nitrogen stocks to soil erosion and land use types in the Loess hilly-gully region of China. Soil Till. Res., 166, 1-9. https://doi.org/10.1016/j.still.2016.10.004

Liu X.B., Zhang X.Y., Wang Y.X., Sui Y.Y., Zhang S.L., Herbert S.J., and Ding G., 2010. Soil degradation: a problem threatening the sustainable development of agriculture in Northeast China. Plant Soil Environ., 56(2), 87-97. https://doi.org/10.17221/155/2009-pse

Maetens W., Vanmaercke M., Poesen J., Jankauskas B., Jankauskienė G., and Ionita I., 2012. Effects of land use on annual runoff and soil loss in Europe and the Mediterranean: A meta-analysis of plot data. Prog. Phys. Geogr., 36(5), 12-55. https://doi.org/10.1177/0309133312451303

Martinez-Casasnovas J.A., and Ramos M.C., 2009. Soil alteration due to erosion, ploughing and levelling of vineyards in north east Spain. Soil Use Manag., 25(2), 183-192. https://doi.org/10.1111/j.1475-2743.2009.00215.x

Mendyk L., Markiewicz M., and Świtoniak M., 2014. Catchments of disappearing lakes in glacial meltwater land- 
scapes (Brodnica Lake District). In: Soil Sequences Atlas (Eds M. Świtoniak, P. Charzyński). Nicolaus Copernicus University Press, Torun, Poland.

Mendyk L., Markiewicz M., Bednarek R., Świtoniak M., Gamrat W.W., Krześlak I., Sykula M., Gersztyn L., and Kupniewska A., 2016. Environmental changes of a shallow kettle lake catchment in a young glacial landscape (Sumowskie Lake catchment), North-Central Poland. Quatern. Int., 418, 116-131.

https://doi.org/10.1016/j.quaint.2015.10.008

Meteorological Bulletin of Laukuva Meteorological Station, 1960-2012, 2012. Lithuanian Hydrometeorological Service under the Ministry of Environment, Vilnius, Lithuania.

Moore I. and Wilson J., 1992. Length-slope factors for the revised universal soil loss equation - simplified method of estimation. J. Soil Water Conserv., 475), 423-428.

Morgan R.P.C., 2005. Soil Erosion and Conservation. Blackwell Publishing, Oxford, United Kingdom.

Mroczek P. and Rodzik J., 2011. Genetic interpretation of micromorphological features of gully loess-soil deposits (case study: Kolonia Celejów, E Poland). Landform Analysis, 17, 125-130.

Mukundan R., Pradhanang S.M., Schneiderman E.M., Pierson D.C., Anandhi A., Zion M.S., Matonse A.H., Lounsbury D.G., and Steenhuis T.S., 2013. Suspended sediment source areas and future climate impact on soil erosion and sediment yield in a New York City water supply watershed, USA. Geomorphology, 183(1), 110-119. https://doi.org/10.1016/j.geomorph.2012.06.021

Nacinovic M.G.G., Mahler C.F., and Avelar A., 2014. Soil erosion as a function of different agricultural land use in Rio de Janeiro. Soil Till. Res., 144, 164-173. https://doi.org/10.1016/j.still.2014.07.002

Nearing M.A., Jetten V., Baffaut C., Cerdan O., Couturier A., Hernandez M., Le Bissonnais Y., Nichols M.H., Nunes J.P., Renschler C.S., Souchère V., and Van Oost K., 2005. Modeling response of soil erosion and runoff to changes in precipitation and cover. Catena, 61(2-3), 131-154. https://doi.org/10.1016/j.catena.2005.03.007

Nikitin B.A., 1999. Method for the determination of soil humus (in Russian). Agrochemistry, 3(2), 156-158.

Øygarden L., 2003. Rill and gully development during an extreme winter runoff event in south-eastern Norway. Catena, 50(2-4), 217-242. https://doi.org/10.1016/s0341-8162(02)00138-8

Pajarskaitė A., 1965. Eroded Soils (in Lithuanian). Vilnius: Mintis, Lithuania.

Panagos P., Borrelli P., Poesen J., Ballabio C., Lugato E., Meusburger K., Montanarella L., and Alewell C., 2015. The new assessment of soil loss by water erosion in Europe. Environ. Sci. Policy, 54, 438-447. https://doi.org/10.1016/j.envsci.2015.08.012

Pennock D.J., Anderson D.W., and de Jong E., 1994. Landscape-scale changes in indicators of soil quality due to cultivation in Saskatchewan, Canada. Geoderma, 64(1-2), 1-19. https://doi.org/10.1016/0016-7061(94)90086-8

Pierson F.B. and Mulla D.J., 1990. Aggregate stability in the Palouse region of Washington: effect of landscape position. Soil Sci. Soc. Am. J., 54(5), 1407-1412. https://doi.org/10.2136/sssaj1990.03615995005400050033x
Podlasiński M., 2013. Denudation of anthropogenic impact on the diversity of soil cover and its spa-tial structure in the agricultural landscape of moraine (in Polish). West Pomeranian University of Technology, Szczecin, Poland.

Poesen J., 1992. Mechanisms of overland-flow and sediment production on loamy and sandy soils with and without rock fragments. In: Overland Flow Hydraulics and Erosion Mechanics (Eds A. Parsons, A.D. Abrahams). UCL Press Limited, University College, London, UK.

Poesen J., Verstraeten G., Soenens R., and Seynaeve L., 2001. Soil losses due to harvesting of chicory roots and sugar beet: an underrated geomorphic process? Catena, 43(1), 35-47. https://doi.org/10.1016/s0341-8162(00)00125-9

Ritchie J.C., Nearing M.A., Nichols M.H., and Ritchie C.A., 2005. Patterns of soil erosion and redeposition on Lucky Hills watershed, Walnut Gulch experimental watershed, Arizona. Catena, 61(2-3), 122-130. https://doi.org/10.1016/j.catena.2005.03.012

Romero-Díaz A., Alonso-Sarriá F., and Martínez-Lloris M., 2007. Erosion rates obtained from check-dam sedimentation (SE Spain). A multi-method comparison. Catena, 71(1), 172-178. https://doi.org/10.1016/j.catena.2006.05.011

Ruysschaert G., Poesen J., Verstraeten G., and Govers G., 2005. Interannual variation of soil losses due to sugar beet harvesting in West Europe. Agr. Ecosyst. Environ., 107(4), 317-329. https://doi.org/10.1016/j.agee.2004.12.005

Savenije H.H.G., 1996. The runoff coefficient as the key to moisture recycling. J. Hydrol., 176 (1-4), 219-225. https://doi.org/10.1016/0022-1694(95)02776-9

Sewerniak P., Gonet S.S., and Quaium M., 2012. Impact of soil preparation with rotary tiller on growth of Scots pine plants on poor sites of the Bydgoszcz Forest (in Polish). Sylwan, 156(11), 871-880.

Sewerniak P. and Mendyk L., 2015. Secondary succession of trees in the dune landscape of the "Glinki" long-term research area - analysis with GIS (in Polish). Forest Res. Pap., 76(2), 122-128. https://doi.org/10.1515/frp-2015-0012

Smolska E., 2002. The intensity of soil erosion in agricultural areas in North-Eastern Poland. Land-form Analysis, 3, 25-33.

Smolska E., 2011. Relation between radiocarbon, archaeological dating and sediment properties on the example of colluvial deposits (NE Poland). Geochronometria, 38(4), 325-333. https://doi.org/10.2478/s13386-011-0025-6

SRM_LT, 2017. Spatial Relief Model. Lithuanian State Land Fund database.

Steegen A., Govers G., Nachtergaele J., Takken I., Beuselinck L., and Poesen J., 2000. Sediment export by water from an agricultural catchment in the Loam Belt of central Belgium. Geomorphology, 33(1), 25-36. https://doi.org/10.1016/s0169-555x(99)00108-7

Sun W., Shao Q., Liu J., and Zhai J., 2014. Assessing the effects of land use and topography on soil erosion on the Loess Plateau in China. Catena, 121, 151-163. https://doi.org/10.1016/j.catena.2014.05.009

Świtoniak M., 2014. Use of soil profile truncation to estimate influence of accelerated erosion on soil cover transformation in young morainic landscapes, North-Eastern Poland. Catena, 116, 173-184. https://doi.org/10.1016/j.catena.2013.12.015 
Świtoniak M., 2015. Issues relating to classification of colluvial soils in young morainic areas (Chełmno and Brodnica Lake District, northern Poland). Soil Sci. Ann., 66(2), 57-66. https://doi.org/10.1515/ssa-2015-0020

Świtoniak M., Charzyński P., and Mendyk L., 2014. Agricultural areas within hummocky moraine plateaus of Poland (Brodnica Lake District). In: Soil Sequences Atlas (Eds M. Świtoniak, P. Charzyński), Nicolaus Copernicus University Press, Toruń, Poland.

Świtoniak M., Mroczek P., and Bednarek R., 2016. Luvisols or Cambisols? Micromorphological study of soil truncation in young morainic landscapes - case study: Brodnica and Chełmno Lake Districts (North Poland). Catena, 137, 583-595. https://doi.org/10.1016/j.catena.2014.09.005

Tripolskaja L., 2005. Organic fertilisers and their effect on the environment (in Lithuanian). Lithuanian Institute of Agriculture, Kèdainiai, Lithuania.

Van Asselen S. and Verburg P.H., 2012. A Land System representation for global assessments and land-use modeling. Global Change Biol., 18(10), 3125-3148. https://doi.org/10.1111/j.1365-2486.2012.02759.x

Van Rompaey A.J.J., Verstraeten G., Van Oost K., Govers G., and Poesen J., 2001. Modelling mean annual sediment yield using a distributed approach. Earth Surf. Process. Landf., 26(11), 1221-1236. https://doi.org/10.1002/esp.275

Vanmaercke M., Maetens W., Poesen J., Jankauskas B., Jankauskienė G., Verstraeten G., and de Vente J., 2012. A comparison of measured catchment sediment yields with measured and predicted hillslope erosion rates in Europe. J. Soils Sediments, 12(4), 586-602. https://doi.org/10.1007/s11368-012-0479-z
Wander M., 2009. Agroecosystem integrity and the internal cycling of nutrients. In: Sustainable agroecosystem management: integrating ecology, economics and society (Eds P. Bohlen, G. House). CRC Press, 137-166. https://doi.org/10.1201/9781420052152.ch10

Zachar D., 1982. Soil erosion. Developments in soil science. Elsivier Scientific, New York, USA.

Zagórski Z. and Kisiel M., 2014. Soils developed from red clays of the Lower Triassic in the north-western part of the Świętokrzyskie Mountains. In: Soil Sequences Atlas (Eds M. Świtoniak, P. Charzyński), Nicolaus Copernicus University Press, Toruń, Poland.

Zádorová T., Jakšík O., Kodešová R., and Penížek V., 2011. Influence of terrain attributes and soil properties on soil aggregate stability. Soil Water Res., 6 (3), 111-119. https://doi.org/10.17221/15/2011-swr

Zádorová T., Zidala D., Penížek V., and Cejková Š., 2014. Relating extent of colluvial soils to topographic derivatives and soil variables in a Luvisol sub-catchment. Soil Water Res., 9 (2), 47-57. https://doi.org/10.17221/57/2013-swr

Zhang C., Wang X., Zou X., Tian J., Liu B., Li J., Kang L., Chen H., and Wu Y., 2018. Estimation of surface shear strength of undisturbed soils in the eastern part of northern China's wind erosion area. Soil Till. Res., 178, 1-10. https://doi.org/10.1016/j.still.2017.12.014

Zhao P., Li S., Wang E., Chen X., Deng J., and Zhao Y., 2018. Tillage erosion and its effect on spatial variations of soil organic carbon in the black soil region of China. Soil Till. Res., 178: 72-81. https://doi.org/10.1016/j.still.2017.12.022 